Jean-François Hardy MD FRCPC, Jean Perrault PhD, Normand Tremblay MD FRCPC,

Danielle Robitaille MD FRCPC, Robert Blain MD FRCPC, Michel Carrier MD FRCSC

\title{
The stratification of cardiac surgical pro- cedures according to use of blood products: a retrospective analysis of 1480 cases
}

be planned to examine the efficiency of blood conservation strategies.

The use of blood products in 1480 consecutive cases of adult cardiac surgical procedures over a period of $15 \mathrm{mth}$ was studied retrospectively using the database of the Deparment of Anaesthesia of the Institut de Cardiologie de Montréal. Use of blood products was compared in patients having (I) coronary artery bypass grafting. (2) valvular surgery, (3) or a combination of I and 2. First operations were compared with reoperations. Overall, the use of homologous blood products was greatest in patients of Group 3, intermediate in patients of Group 2, and smallest in patients of Group 1. Reoperations were associated with an increase in intrnoperative transfusion of packed red blood cells, but postoperative chest drainage was similar to first operations. When all blood products (packed red blood cells, fresh frozen plasma and platelets) were taken into consideration, patients undergoing primary $C A B G$ or valve surgery were the least exposed to homologous blood donors (five and six units transfused respectively). Repeat CABG was associated with an intermediate exposure to homologous blood products (eight units). Finally, primary and repeat combined procedures, and repeat valve surgery were associated with the greatest exposure to foreign blood products (10,13 and 10 units respectively). The data presented in this study provide a rational basis for stratification of procedures according to the expected use of blood products, particularly in view of future studies which may

\section{Key words}

BLOOD: loss, replacement;

SURGERY: cardiac;

TRANSFUSION: stored blood.

From the Departments of Anaesthesia, Haematology and Surgery, University of Montreal, Montreal, Quebec

Address correspondence to: Dr Jean-François Hardy,

Département d'Anesthésie, Institut de Cardiologie de Montréal, 5000 est rue Bélanger, Montréal, Québec, HIT IC8.

Accepted for publication 14ih January, 1991.
Cette étude rétrospective rapporte l'utilisation des produits sanguins en chirurgie cardiaque de l'adulte a l'Institut de Cardiologie de Montréal chez 1480 patients opérés sous circulation extra-corporelle entre novembre 1988 et avril 1990. Les patients ont été regroupés selon l'intervention subie: I) la revascularisation myocardique, 2) la chirurgie valvulaire, 3) une combinaison de l et de 2 . Nous avons également comparé les interventions de première intention avec les réinterventions. Au total, les besoins en produits sanguins homologues ont éré les plus considérables chez les patients du groupe 3, intermédiaires chez les patients du groupe 2 , et les plus faibles chez les patients du groupe 1. Les réinterventions ont été associées à une augmentation des transfusions de culots globulaires durant ln chirurgie, mais non à des pertes sanguines post-opératoires accrues. Lorsque tous les produits sanguins som pris en considération (culots globulaires, plasina, plaquettes), l'exposition (en nombre d' unités) aux produits sanguins homologues était la plus faible chez les patients subissant une première chirurgie de revascularisation (cinq unités) ou une chirurgie valvulaire de première intention (six unités). Dans la réintervention pour revascularisation myocardique l'exposition était intermédiaire (huit unités), alors qu'elle était la plus forte dans la chirurgie combinée, qu' elle soit primaire ou de réintervention (10 ou 13 unités). Les données présentées dans celte étude permettent de stratifier les chirurgies en fonction des besoins transfusionnels prévus et devraient nous guider dans la gestion des technologies visant à diminuer les pertes sanguines et l'exposition aux produits sanguins homologues en chirurgie cardiaque de l'adulte.

Excessive bleeding after cardiopulmonary bypass (CPB) has always been a major concern to cardiac anaesthetists and surgeons. In an effort to reduce morbidity associated 
with transfusion of blood products (transmitted infectious diseases, transfusion reactions, etc ... ) and to answer concerns that the demand for blood and blood products may exceed the supply, many strategies have been explored to diminish the need for transfusions both during and after CPB. While most centres now routinely use a nonhaemic prime in the oxygenator, more specific blood conservation strategies have been studied, alone or in combination. They include: intraoperative autotransfusion, ' salvage and transfusion of all blood in the oxygenator at the conclusion of bypass, ${ }^{2}$ use of a membrane oxygenator, ${ }^{3}$ postoperative return of shed mediastinal blood, ${ }^{4-6}$ predonation of autologous blood, ${ }^{7}$ use of nonhaemic volume expanders, ${ }^{2,4}$ normovolaemic haemodilution, ${ }^{2,4,7}$ and pharmacological manipulation with desmopressin, ${ }^{8}$ dipyridamole, ${ }^{3} \Sigma$-aminocaproic acid, ${ }^{9}$ tranexamic acid ${ }^{10}$ and aprotinine. $"$

All these modalities have their advantages, disadvantages and incur expenses to some degree. Pharmacological reduction of bleeding associated with CPB has received much attention recently. It has the main advantage of being readily available and easy to administer, of avoiding the use of costly equipment, and may be used prophylactically rather than therapeutically in some instances. However, the cost of some of these drugs may also be considerable. Efficiency has now become a major factor in the decision to approve any therapeutic modality by hospital administrators (an efficiency study aims to show what is the most efficient intervention in terms of cost, personnel, compliance, etc ... given that more than one alternative is available). ${ }^{12}$ For example, based on the demonstration of reductions of blood loss and improved haemostasis in patients undergoing $\mathrm{CPB}$, two recent publications have recommended the routine use of aprotinin for open-heart surgery. ${ }^{13,14}$ While such a treatment is efficacious (an efficacy study attempts to demonstrate that a new intervention works in an ideal setting) ${ }^{12}$ and may eventually prove to be effective (an effectiveness study attempts to demonstrate that an intervention works in the real world), ${ }^{12}$ it carries a substantial cost. Surgical skill, the use of various anaesthetic techniques, differing CPB circuits, awareness of the risks associated with blood products and the setting of stricter criteria for transfusion are but a few of the variables which may differ from one institution to another. Since it is generally accepted that not all groups of cardiac surgical patients are equally exposed to blood products but few data are available to substantiate this clinical impression, we felt it necessary (from an efficiency standpoint) to identify precisely those patient populations most at risk of bleeding, in view of eventually implementing efficient strategies to reduce the need for transfusion of blood products in those patients.

\section{Methods}

We report the blood losses and the practice of blood replacement in 1480 consecutive cases of adult cardiac surgery using CPB compiled from the database of the department of anaesthesia of the Institut de Cardiologie de Montréal in the period extending from November 14th 1988 to April 1990. Preoperative and intraoperative data were collected in the operating room (OR) by the anaesthetist who completed a special data collection form for every patient undergoing surgery. This form was then transmitted to a research assistant who, in turn, collected information pertaining to the postoperative period. Finally, the secretary of the department of anaesthesia entered the information in a database created with Fourth Dimension (Copyright ${ }^{\odot} 1989$ ACIUS, Inc. and $\mathrm{ACI}$ ), using a Macintosh II personal computer.

Data analysis included transfusion of packed red blood cells (PRBC) during the operation, transfusion of PRBC, fresh frozen plasma (FFP) and platelets during the first seven postoperative days, blood loss into pericardial and mediastinal drains in the first $24 \mathrm{hr}$ after surgery, and haemoglobin concentration on the seventh postoperative day or prior to discharge, whichever came first. Patients were grouped as having (1) coronary artery bypass grafting with saphenous vein grafts and/or mammary artery implants (CABG), (2) valvular surgery, (3) a combination of 1 and 2 , and (4) miscellaneous procedures (these essentially include cardiac transplantations, closure of an atrial septal defect, aortic arch surgery and electrophysiological procedures). Furthermore, use of blood products in the sub-group of patients having reoperations was compared with that of patients undergoing a first operation. Finally, use of blood products was analysed according to the name of the attending anaesthetist, name of the attending surgeon, age and body surface area (BSA) of patients, and duration of aortic cross-clamp and cardiopulmonary bypass (CPB).

The usual management of anaesthesia and CPB at the Institut de Cardiologie de Montréal is as follows. A preoperative haematological evaluation is performed to ensure an optimal coagulation status. Patients receive medication with im morphine sulfate $0.1-0.15 \mathrm{mg} \cdot \mathrm{kg}^{-1}$ and scopolamine $0.4 \mathrm{mg} 60$ to $90 \mathrm{~min}$ before arrival in the OR. Anaesthesia is induced with a combination of a benzodiazepine (diazepam or midazolam) and an opioid (fentanyl $50 \mu \mathrm{g} \cdot \mathrm{kg}^{-1}$ sufentanil $5-8 \mu \mathrm{g} \cdot \mathrm{kg}^{-1}$ or morphine $2 \mathrm{mg} \cdot \mathrm{kg}^{-1}$ ), and supplemented with a volatile agent as necessary. Pancuronium, alone or in combination with vecuronium, is used to provide muscular relaxation. Heparin $\left(300 \mathrm{IU} \cdot \mathrm{kg}^{-1}\right)$ is injected into the right atrium by the surgeon before cannulation of the heart. Additional heparin is administered by the anaesthetist to maintain the 
TABLE I Use of blood products according to type of operation

\begin{tabular}{lllll}
\hline & & $\begin{array}{l}\text { Total RBC } \\
\text { transfused } \\
\text { (units) }\end{array}$ & $\begin{array}{l}\text { ICU transfusion } \\
F F P \text { (units) }\end{array}$ & $\begin{array}{l}\text { ICU iransfusion } \\
\text { platelets (umits) }\end{array}$ \\
\hline (1) CABG & $n$ & $2.8 \pm 3.7$ & $1.4 \pm 2.8$ & $1.1 \pm 3.4$ \\
(2) Valve surgery & 1073 & $4.0 \pm 4.2$ & $1.6 \pm 3.0$ & $2.1 \pm 5.3$ \\
(3) CABG + valve & 271 & $5.4 \pm 5.1$ & $2.2 \pm 3.0$ & $3.2 \pm 5.3$ \\
(4) Miscellaneous & 61 & $3.6 \pm 5.3$ & $1.2 \pm 2.5$ & $1.8 \pm 3.8$ \\
$P$ value & 75 & $<0.05$ & NS & 0.0001 \\
\hline
\end{tabular}

All results mean $\pm \mathrm{SD}$.

activated clotted time over $400 \mathrm{sec}$. A bubble oxygenator (Bentley 10 plus, Bentley Laboratories Inc., CA) is primed with $1500-2000 \mathrm{ml}$ of crystalloid solution containing 5000 units heparin and flows of $2.4 \mathrm{~L} \cdot \mathrm{min}^{-1} \cdot \mathrm{m}^{-2}$ (normothermia) to $1.8 \mathrm{~L} \cdot \mathrm{min}^{-1} \cdot \mathrm{m}^{-2}$ (hypothermia) are obtained with a Sarns (Sarns Inc., Ann Arbor, Mich.) roller pump. Patients receive pentobarbital $3-4 \mathrm{mg} \cdot \mathrm{kg}^{-1}$ at the onset of CPB. Systemic hypothermia to $28^{\circ} \mathrm{C}$ (urinary bladder temperature) is maintained during aortic cross-clamping and the myocardium is preserved by infusion of cold crystalloid cardioplegic solution into the aortic root. After separation from CPB, the effects of residual heparin are reversed with sufficient protamine sulfate $\left(1-1.5 \mathrm{mg} \cdot 100 \mathrm{IU}^{-1}\right.$ heparin) to return the ACT to the prebypass value. Blood remaining in the CPB circuit after separation is collected and reinfused to the patient, according to haemodynamic status. In the presence of a normal ACT and important bleeding, desmopressin acetate $0.3 \mu \mathrm{g} \cdot \mathrm{kg}^{-1}$ is administered while a coagulogram is ordered with a view to initiating specific therapy. Should bleeding persist and results of coagulation testing not be available, empirical treatment of the suspected coagulopathy is initiated with fresh frozen plasma and/or platelets.

The attending anaesthetist is responsible for the administration of all blood products in the OR. While there are no written policies on the administration of PRBC, the usual practice is to maintain a haemoglobin concentration of $70 \mathrm{~g} \cdot \mathrm{L}^{-1}$ during CPB. Pre- or post-CPB haemoglobin concentrations as low as $80 \mathrm{~g} . \mathrm{L}^{-1}$ are tolerated as long as haemodynamic stability is maintained. Human albumin is used when volume expansion alone is required. Plasma is not used for this purpose at our institution.

After transfer to the intensive care unit (ICU), the patient is placed on synchronised intermittent mandatory ventilation with a positive end-expiratory pressure of $5-10 \mathrm{~cm} \mathrm{H} \mathrm{H}_{2} \mathrm{O}$. Losses into the chest drains are measured hourly and recorded. Blood products are infused as prescribed by the attending surgeon to maintain an appropriate haemodynamic status, an acceptable haemo- globin concentration $\left(80-100 \mathrm{~g} \cdot \mathrm{L}^{-1}\right)$, and to correct coagulation abnormalities resulting in clinically important bleeding.

Results are given as mean \pm standard deviation (SD). Results were analysed by one-way analysis of variance and Scheffe's F-test. Statistical significance was established when $P \leq 0.05$.

\section{Results}

The population studied during a period of $15 \mathrm{mth}$ was composed of $72 \%$ males and $28 \%$ females, had a mean age of $58 \mathrm{yr}$, with $67 \%$ of patients under the age of 65 and $33 \%$ of patients over the age of 65 .

Overall blood requirements are shown in Table $I$. Transfusion of PRBC and platelets was least in patients operated upon for myocardial revascularization (Group 1) and most in patients operated upon for valvular surgery associated with myocardial revascularisation (Group 3 ). Valvular surgery (Group 2) and miscellaneous procedures (Group 4) had intermediate requirements for PRBC and platelets. These differences were statistically significant by analysis of variance ( $P=0.0001)$. Transfusion of FFP was not different among groups.

When first operations were compared (ANOVA; data in Table II), Group 3 patients received more PRBC both during surgery $(\mathrm{P}<0.001)$ and in the $\operatorname{ICU}(P=0.0001)$ than patients in the other three groups. More platelets were transfused in Groups 2 and 3 than in Group 1 ( $P=$ $0.0001)$. Transfusion of FFP, postoperative mediastinal drainage, and postoperative haemoglobin concentration were not significantly different among groups.

When reoperations were compared (ANOVA; data in Table II), patients undergoing repeat myocardial revascularization procedures received less PRBC during surgery than patients in the other three groups $(P<0.05)$. Transfusion of PRBC and of other blood products in the ICU, postoperative mediastinal drainage, and postoperative haemoglobin concentration were not different among these four sub-groups.

Table II further compares first operations with reopera- 
TABLE Il Transfusions, chest drainage and discharge haemoglobin concentration for first operation and reoperation

\begin{tabular}{|c|c|c|c|c|c|c|c|c|}
\hline & $n$ & $\begin{array}{l}\text { OR transfusion } \\
\text { packed } R B C \\
\text { (unirs) }\end{array}$ & $\begin{array}{l}\text { ICU transfusion } \\
\text { packed } R B C \\
\text { (units) }\end{array}$ & $\begin{array}{l}\text { Total PRBC } \\
\text { transfused } \\
\text { (units) }\end{array}$ & $\begin{array}{l}\text { ICU transfusion } \\
F F P \\
\text { (units) }\end{array}$ & $\begin{array}{l}\text { ICU transfusion } \\
\text { platelets } \\
\text { (units) }\end{array}$ & $\begin{array}{l}\text { Post-op chest } \\
\text { drainage } \\
\text { (Int) }\end{array}$ & $\begin{array}{l}\text { Post-op } \\
\text { haemoglobin } \\
\left(g \cdot L^{-1}\right)\end{array}$ \\
\hline CABG & 972 & $0.9 \pm 1.4$ & $1.9 \pm 1.9$ & $2.8 \pm 2.5$ & $1.4 \pm 2.6$ & $0.9 \pm 2.8$ & $637 \pm 590$ & $96 \pm 38$ \\
\hline Reoperation & 101 & $1.6 \pm 1.9$ & $2.9 \pm 3.2$ & $3.5 \pm 3.8$ & $1.4 \pm 4.1$ & $2.9 \pm 6.6$ & $525 \pm 740$ & $93 \pm 37$ \\
\hline$P$ & & 0.0001 & NS & $<0.01$ & NS & 0.0001 & NS & NS \\
\hline Valve surgery & 158 & $1.1 \pm 1.8$ & $1.9 \pm 2.0$ & $3.0 \pm 2.7$ & $1.4 \pm 2.4$ & $1.8 \pm 5.2$ & $598 \pm 966$ & $98 \pm 30$ \\
\hline Reoperation & 113 & $2.7 \pm 3.9$ & $2.7 \pm 2.9$ & $5.4 \pm 5.3$ & $2.1 \pm 3.7$ & $2.5 \pm 5.4$ & $667 \pm 1040$ & $88 \pm 39$ \\
\hline$P$ & & 0.0001 & $<0.01$ & 0.0001 & $<0.05$ & NS & NS & $<0.05$ \\
\hline CABG + valve & 47 & $1.8 \pm 1.5$ & $3.3 \pm 3.9$ & $5.2 \pm 4.6$ & $2.1 \pm 3.1$ & $2.8 \pm 5.0$ & $628 \pm 704$ & $96 \pm 31$ \\
\hline Reoperation & 14 & $3.5 \pm 4.0$ & $2.8 \pm 2.9$ & $6.3 \pm 6.7$ & $2.4 \pm 2.9$ & $4.4 \pm 6.1$ & $1049 \pm 980$ & $80 \pm 45$ \\
\hline$P$ & & $<0.05$ & NS & NS & NS & NS & NS & NS \\
\hline Miscellaneous & 57 & $1.4 \pm 4.1$ & $1.5 \pm 1.7$ & $2.9 \pm 4.9$ & $0.7 \pm 1.6$ & $1.3 \pm 3.2$ & $419 \pm 535.0$ & $93 \pm 37$ \\
\hline Reoperation & 18 & $3.3 \pm 4.5$ & $2.8 \pm 2.6$ & $6.1 \pm 5.8$ & $2.7 \pm 3.9$ & $3.3 \pm 5.0$ & $650 \pm 777$ & $74 \pm 55$ \\
\hline$P$ & & NS & $<0.05$ & $<0.05$ & $<0.01$ & $<0.05$ & NS & NS \\
\hline \multicolumn{9}{|c|}{$\begin{array}{l}P \text { value for comparison } \\
\text { of first operations }\end{array}$} \\
\hline (ANOVA) & & $<0.001$ & 0.0001 & 0.0001 & NS & 0.0001 & NS & NS \\
\hline \multicolumn{9}{|c|}{$\begin{array}{l}P \text { value for comparison } \\
\text { of reoperations }\end{array}$} \\
\hline (ANOVA) & & $<0.05$ & NS & $<0.05$ & NS & NS & NS & NS \\
\hline
\end{tabular}

All results mean $\pm \mathrm{SD}$.

tions in each group of patients. Patients in Group 1 undergoing a reoperation received more PRBC (during surgery: $P=0.0001$; total: $P<0.01)$ and platelets $(P=$ 0.0001 ), but transfusion of PRBC (in the ICU) and FFP, mediastinal blood loss and postoperative haemoglobin concentration were not different from a first operation.

Patients in Group 2 received more PRBC (during surgery: $P=0.0001$, in the ICU: $P<0.01$, and total: $P=$ $0.0001)$ and FFP $(P<0.05)$ when undergoing a reoperation. Transfusion of platelets and blood losses in the mediastinal drains were not affected by reoperation. Reoperation was associated with a lower haemoglobin concentration upon leaving the hospital $(P<0.05)$.

Patients in Group 3 received more PRBC (during surgery: $P<0.05$ ) upon reoperation. However, ICU and total transfusion of blood products, mediastinal blood losses and postoperative haemoglobin concentration were not modified by reoperation.

Reoperation was associated with an increase in ICU ( $P$ $<0.05)$ and total $(P<0.05)$ transfusion of PRBC, FFP $(P<0.01)$ and platelets $(P<0.05)$ in patients of Group 4. Mediastinal blood losses were not increased by reoperation. Transfusion of PRBC during surgery tended to be greater and postoperative haemoglobin concentration tended to be lesser in reoperated patients, but not statistically so.

Transfusion of PRBC in the OR and in the ICU, and transfusion of FFP were different when analysed accord- ing to the attending anaesthetist (Table III). However, when anaesthetist number six was excluded owing to his small number of cases, there was no difference in the total number of PRBC and FFP transfused per patient ( $P=$ 0.13 and 0.27 respectively).

Similarly, when analysing use of blood products according to the attending surgeon (Table IV), a small difference in OR transfusion of PRBC was noted (ANOVA; $P<0.05$ ). However, total transfusion of PRBC per patient was not different. Surgeon number eight transfused more FFP than others (ANOVA; $P<0.01$ ). No difference was noted when analysing postoperative chest drainage and postoperative haemoglobin concentrations according to the attending surgeon.

Finally, use of blood products could not be correlated with age, BSA, duration of aortic cross-clamp or duration of CPB.

\section{Discussion}

The primary goal of the present study was to identify the population most at risk of bleeding associated with cardiac surgery and $\mathrm{CPB}$, with a view to implementing efficient strategies to reduce the need for transfusion of blood products in those patients. From the data presented in Table II, it may be inferred that patients undergoing primary $\mathrm{CABG}$ or valve surgery were the least exposed to homologous blood donors, receiving an average of five and six units of any blood product respectively. Repeat 
TABLE III Use of blood products according to altending anaesthetist

\begin{tabular}{|c|c|c|c|c|c|c|c|c|}
\hline Anaestherist & $n$ & $\begin{array}{l}\text { OR transfusion } \\
\text { packed } R B C \\
\text { (units) }\end{array}$ & $\begin{array}{l}\text { JCU iransfusion } \\
\text { Packed RBC } \\
\text { (lmits) }\end{array}$ & $\begin{array}{l}\text { Total RBC } \\
\text { transfused } \\
\text { (units) }\end{array}$ & $\begin{array}{l}\text { ICU transfusion } \\
\text { FFP (units) }\end{array}$ & $\begin{array}{l}\text { ICU iransfusion } \\
\text { plarelets (units) }\end{array}$ & $\begin{array}{l}\text { Post-op chest } \\
\text { drainage (ml) }\end{array}$ & $\begin{array}{l}\text { Post-op } \\
\text { haemoglobin } \\
\left(g \cdot L^{-1}\right)\end{array}$ \\
\hline I & 277 & $0.6 \pm 2.2$ & $2.2 \pm 1.9$ & $2.8 \pm 3.2$ & $1.2 \pm 2.1$ & $1.3 \pm 4.0$ & $569 \pm 614$ & $93 \pm 39$ \\
\hline 2 & 236 & $1.2 \pm 2.5$ & $2.1 \pm 2.1$ & $3.3 \pm 3.6$ & $1.7 \pm 2.6$ & $1.3 \pm 3.9$ & $564 \pm 569$ & $94 \pm 39$ \\
\hline 3 & 200 & $1.3 \pm 2.1$ & $2.2 \pm 2.5$ & $3.5 \pm 3.8$ & $1.7 \pm 2.8$ & $1.6 \pm 3.9$ & $663 \pm 651$ & $96 \pm 38$ \\
\hline 4 & 246 & $1.2 \pm 1.9$ & $1.9 \pm 2.5$ & $3.1 \pm 3.3$ & $1.6 \pm 3.3$ & $1.5 \pm 4.6$ & $665 \pm 820$ & $97 \pm 33$ \\
\hline 5 & 225 & $1.3 \pm 2.0$ & $2.3 \pm 2.6$ & $3.6 \pm 3.4$ & $1.6 \pm 3.8$ & $1.6 \pm 3.9$ & $714 \pm 839$ & $93 \pm 36$ \\
\hline 6 & 42 & $1.0 \pm 2.0$ & $1.1 \pm 1.4$ & $2.1 \pm 2.6$ & $0.4 \pm 0.9$ & $0.9 \pm 2.7$ & $511 \pm 403$ & $107 \pm 22$ \\
\hline 7 & 254 & $1.7 \pm 1.7$ & $1.6 \pm 2.0$ & $3.3 \pm 2.9$ & $1.3 \pm 2.3$ & $1.2 \pm 3.4$ & $601 \pm 717$ & $96 \pm 38$ \\
\hline$P$ value & & 0.0001 & $<0.01$ & $<0.05$ & $<0.05$ & NS & NS & NS \\
\hline
\end{tabular}

All results mean $\pm \mathrm{SD}$.

TABLE IV Use of blood products according to attending surgeon

\begin{tabular}{|c|c|c|c|c|c|c|c|c|}
\hline Surgeon & $n$ & $\begin{array}{l}\text { OR transfusion } \\
\text { packed } R B C \\
\text { (units) }\end{array}$ & $\begin{array}{l}\text { ICU iransfusion } \\
\text { Packed } R B C \\
\text { (units) }\end{array}$ & $\begin{array}{l}\text { Total RBC } \\
\text { transfused } \\
\text { (units) }\end{array}$ & $\begin{array}{l}\text { ICU transfusion } \\
\text { FFP (tunits) }\end{array}$ & $\begin{array}{l}\text { ICU transfision } \\
\text { platelets (units) }\end{array}$ & $\begin{array}{l}\text { Post-op chest } \\
\text { drainage (ml) }\end{array}$ & $\begin{array}{l}\text { Post-op } \\
\text { haemoglobin } \\
\left(g \cdot L^{-1}\right)\end{array}$ \\
\hline 1 & 81 & $1.5 \pm 3.7$ & $1.7 \pm 2.0$ & $3.2 \pm 4.5$ & $0.9 \pm 1.5$ & $1.2 \pm 3.4$ & $633 \pm 689$ & $102 \pm 24$ \\
\hline 2 & 195 & $1.5 \pm 2.9$ & $2.0 \pm 2.1$ & $3.5 \pm 4.1$ & $1.4 \pm 2.8$ & $1.1 \pm 3.8$ & $677 \pm 881$ & $90 \pm 38$ \\
\hline 3 & 230 & $1.3 \pm 2.0$ & $1.9 \pm 2.5$ & $3.2 \pm 3.4$ & $1.4 \pm 2.7$ & $1.6 \pm 4.6$ & $554 \pm 796$ & $94 \pm 37$ \\
\hline 4 & 201 & $1.4 \pm 3.5$ & $2.0 \pm 1.8$ & $3.4 \pm 3.4$ & $1.2 \pm 2.2$ & $1.2 \pm 3.6$ & $575 \pm 525$ & $100 \pm 38$ \\
\hline 5 & 160 & $1.3 \pm 1.9$ & $2.0 \pm 2.6$ & $3.3 \pm 3.3$ & $1.4 \pm 2.4$ & $1.3 \pm 3.6$ & $640 \pm 711$ & $96 \pm 35$ \\
\hline 6 & 224 & $0.9 \pm 1.4$ & $1.9 \pm 2.2$ & $2.8 \pm 2.9$ & $1.5 \pm 3.5$ & $1.4 \pm 3.8$ & $667 \pm 652$ & $91 \pm 37$ \\
\hline 7 & 170 & $1.1 \pm 1.4$ & $2.0 \pm 1.6$ & $3.1 \pm 2.2$ & $1.8 \pm 2.7$ & $2.1 \pm 4.8$ & $684 \pm 621$ & $95 \pm 36$ \\
\hline 8 & 68 & $1.3 \pm 1.4$ & $2.9 \pm 1.5$ & $4.2 \pm 2.3$ & $2.8 \pm 2.2$ & $0.4 \pm 2.0$ & $611 \pm 558$ & $100 \pm 44$ \\
\hline 9 & $|5|$ & $0.9 \pm 1.2$ & $2.0 \pm 3.1$ & $2.9 \pm 3.4$ & $1.5 \pm 3.5$ & $1.5 \pm 4.2$ & $568 \pm 703$ & $93 \pm 38$ \\
\hline$P$ value & & $<0.05$ & NS & NS & $<0.0$ l & NS & NS & NS \\
\hline
\end{tabular}

All results mean $\pm \mathrm{SD}$.

CABG were associated with a mean exposure to eight units of homologous blood products. Finally, primary and repeat combined procedures, and repeat valve surgery were associated with the greatest exposure to foreign blood products, patients being exposed to an average of 10,13 and 10 units respectively. Miscellaneous procedures formed a very heterogeneous group and, consequently, were associated with such variable exposure to blood products that they will not be considered further.

To be efficient, blood conservation therapies must be adapted to expected blood requirements. While some strategies may be efficient on a routine basis (e.g., use of a nonhaemic prime in the oxygenator), it becomes apparent that other, more specific, blood conservation therapies (e.g., pharmacological manipulation of coagulation) may be efficient in only a small proportion of patients. These include most patients undergoing reoperations and patients undergoing combined valvular-revascularization procedures (first and repeat operations). Repeat CABG is associated with intermediate requirements for blood products. Since repeat CABG accounted for $41 \%$ of reoperations at our institution, careful thought must be given to including or excluding this procedure when a decision is made to bring a new blood conservation strategy into effect.

An interesting and unexpected finding of this study was that postoperative blood loss into the drainage system was not increased by reoperation. This may have resulted from meticulous intraoperative haemostasis by our surgeons, thereby avoiding excessive bleeding in the ICU. Thus, most of the difference in total need for transfusions occurred in the OR. Our clinical impression was that blood loss was most important at the time of dissection but our database did not allow us to differentiate pre- from post-CPB blood loss.

Another surprising finding was that anaesthetists and surgeons had little influence on the use of blood products. While some patients may have received more (or less) PRBC in the OR as a result of individual anaesthetic or surgical practice, these differences were compensated by 
subsequent ICU transfusions and all patients left the hospital with comparable haemoglobin concentrations.

While blood loss during the operation was recorded as a specific entry, we chose to ignore the data because we felt it to be too subjective. On the other hand, transfusion of blood products was well recorded and may easily and reliably be retrieved from the patients' charts. Since postoperative haemoglobin concentrations were similar in all groups, it was our impression that the number of transfused PRBC adequately reflected the total volume of shed blood, with the possible exception of a slight underestimation of blood losses during valvular reoperations. However, transfusions cannot be equated with losses since postoperative haemoglobin concentrations were allowed to decrease substantially, one of the steps taken in view of limiting exposure of patients to donor blood. These low haemoglobin concentrations apppeared to be well tolerated by patients, with no untoward consequences. ${ }^{2,4,7}$

Comparisons with published series are difficult, givan the large number of variables involved and the evolution of the demand for blood in open-heart surgery over time. While an average of nearly eight units of blood was used per case in $1971,{ }^{15}$ reduction of blood transfusion to an average of 2.66 units of blood per patient was reported in 1976. ${ }^{16}$ When reoperations are excluded, coronary artery bypass surgery may be associated with minimal bank blood requirements when effective intraoperative and postoperative blood salvaging techniques are implemented. ${ }^{17.18}$ However, a number of problems has been attributed to intraoperative autologous blood transfusions, in particular bleeding tendencies when large volumes are processed. ${ }^{19}$ Thurer et al. could not demonstrate that retransfusion of postoperatively shed mediastinal blood (as part of a multifaceted approach to blood conservation following cardiac operation) further reduced the use of banked blood. ${ }^{4}$ This may explain why recent studies tend to focus more on the pharmacological prevention of bleeding rather than on methods of salvaging shed blood. Unfortunately, these studies either include a heterogeneous group of operations and do not specify if reoperations were included, 9.10 or demonstrate an effect in a group of patients for whom we feel prophylaxis may not be an efficient therapy, i.e., primary CABG. ${ }^{11,13}$

In summary, this retrospective report on the transfusion of blood products in adult cardiac surgery using CPB indicated that most reoperations and combined valvular and revascularization procedures (first and repeat operations) were associated with the greatest use of blood products. Reoperations for CABG were associated with an intermediate consumption of blood products. Finally, first operations (excluding combined procedures) were associated with the smallest demand for blood products. It is our feeling that future studies on the efficiency of blood conservation strategies should stratify procedures according to the expected use of blood products.

\section{References}

I Mayer ED, Welsch M, Tanzeem A et al. Reduction of postoperative donor blood requirement by use of the cell separator. Scand J Thorac Cardiovasc Surg 1985; 19 : |65-7|.

2 Cosgrove DM, Loop FD, Lytle BW et al. Determinants of blood utilization during myocardial revascularization. Ann Thorac Surg 1985; 40: 380-4.

3 Teoh KH, Christakis GT, Weisel RD et al. Blood conservation with membrane oxygenators and dipyridamole. Ann Thorac Surg 1987: 44: 40-7.

4 Thurer RL, Lytle BW, Cosgrove DM, Loop FD. Aulotransfusion following cardiac operations: a randomized, prospective study. Ann Thorac Surg 1979; 27: 500-7.

5 Schaff HV, Hater JM, Bell WR et al. Autotransfusion of shed mediastinal blood after cardiac surgery. A prospective study. J Thorac Cardiovasc Surg 1978; 75: 632-4I.

6 Johnson RG, Rosenkrantz KR. Preston RA, Hopkins C, Daggett WM. The efficacy of postoperative autotransfusion in patients undergoing cardiac operations. Ann Thorac Surg 1983; 36: 173-9.

7 Love TR, Hendren WG, O'Keefe DD, Daggen WM. Transfusion of predonated autologous blood in elective cardiac surgery. Ann Thorac Surg 1987; 43: 508-12.

8 Salzman EW, Weinstein MJ, Weintraub RM et al. Treatment with desmopressin acelate to reduce blood loss after cardiac surgery. N Engl J Med 1986; 314: 1402-6.

9 DelRossi AJ, Cernaianu AC, Botros S, Lemole GM, Moore $R$. Prophylactic treatment of postperfusion bleeding using EACA. Chest 1989; 96: 27-30.

10 Collier W, Hlavacek J, Horrow JC, Goldman S, Goel $I P$. Prophylactic tranexamic acid decreases blood loss after extracorporeal circulation. Anesthesiology 1988: 69: Al35.

11 Bidstrup BP, Royston D, Sapsford RN, Taylor KM. Reduction in blood loss and blood use after cardiopulmonary bypass with high dose aprotinin (Trasylol). J Cardiovasc Surg 1989; 97: 364-72

12 Cohen MM. Using epidemiology to study adverse outcomes in anaesthesia. Can J Anaesth 1990; 37: Sxlv-viii.

13 van Oeveren $W$, Harder MP, Roozendaal KJ, Eijsman $L$, Wildevuur $C R H$. Aprotinin protects platelets against the initial effect of cardiopulmonary bypass. J Cardiovasc Surg 1990; 99: 788-97.

14 Dietrich W. Hähnel C, Richter JA. Routine application of high-dose aprotinin in open-heart surgery. A study on 1784 patients. Anesthesiology 1990; 73: Al46. 
15 Roche JK. Stengle JM. Open-heart surgery and the demand for blood. JAMA 1973; 225: 1516-21.

16 Tector AJ, Gabriel RP, Mateicka WE, Oparah SS, Flemma $R J$, Lepley $D$. Reduction of blood usage in open heart surgery. Chest 1976; 70: 454-7.

17 Cosgrove DM, Thurer RL, Lylle BW, Gill CG, Peler M, Loop FD. Blood conservation during myocardial revascularization. Ann Thorac Surg 1978; 28: 184-8.

18 Yeh $T$, Shelion L, Yeh TJ. Blood loss and bank blood requirement in coronary bypass surgery. Ann Thorac Surg 1978; 26: 11-6.

19 McDonald D, KaplanJA. Blood and volume expanders. In: Kaplan JA (Ed.). Cardiac Anesthesia, volume 2, Cardiovascular Pharmacology, Orlando: Grune \& Stratton Inc., 1983; 485-523. 